COMPUTING

\section{Expansion Planned?}

A THREE-FOLD increase in the support of computing by the SRC between now and $1975-76$ is recommended by the Computing Science Committee of the council. This encouragement to computing in British universities is intended to produce increased support for research, an expansion in postgraduate courses, a broadening of the activities of the Computer Board of the SRC and a substantial strengthening of the academic staff in computing departments. (Computing Science Review, SRC.)

The changes recommended by the committee imply a level of support for computing in universities of $£ 2$ million in 1975-76, but the committee warns that this might not be possible for lack of manpower. In the long run, however, the committee considers that manpower should be no problem. Of the 210 research students expected to qualify in 1978 , only 52 will be required to maintain the expansion of the university departments. A higher percentage, 18 out of 50 qualifying PhDs and MScs, will be needed in 1973 .

No hard and fast recommendation is made as to how the $£ 2$ million is to be allocated, but the Long Range Computing Research Policy Panel, in a report published as an appendix to that of the Computing Science Committee, recommends that $£ 1.15$ million a year should be spent on research into long range computing and that $£ 300,000$ of this be allocated to the purchase of capital equipment.

To reach the manpower targets set by the committee it is suggested that 165 advanced course studentships and 90 research studentships be allocated in 1972 . In 1975 the recommendations are that there should be 500 advanced course studentships and 210 research studentships-which will produce the predicted 210 qualifiers in 1978. In 1971 the SRC allocated 139 advanced course studentships and 80 research studentships.

The committee hopes that this growth of 30 per cent over the next five years will be financed jointly by the SRC and the universities, but it says that while universities are adjusting to the need for expansion in computer science, special consideration should be given to the appointment of research assistants for longer than the usual three years.

One of the chief concerns of the committee is that an expansion in the application of computers will not be matched by a corresponding increase in the support of theoretical studies and it cites several fields of research which need special attention. These are analysis of programming errors, computer networks and communications, computer systems evaluation and reliability studies, data processing and large data bases, general principles of pattern recognition, machine intelligence, microprogramming and related activities, parallelism in hardware and software, physical and logical structure of computers, programming methodology, software engineering, terminals and peripherals and theory of computation.

The committee emphasizes that its shopping list is not exclusive, and that any promising and apt proposal will be considered. It justifies its recommendation for a rapid increase in postgraduate courses by saying that the present surplus of trained computer personnel is short lived.

On courses, the committee says that syllabuses should be more closely oriented to the needs of the industrial and commercial computer user, and it suggests that there should be a choice of options, which should include in particular numerical analysis, available to the student. The committee also says that arts graduates should be encouraged to apply for SRC studentships and that lecturers for courses should be drawn from a wide field and should, in particular, include people from industry.

\section{PLANT BREEDING} \section{Genes for All Seusons}

Two new strains of high yield, semidwarf, winter wheat have emerged from the Agricultural Research Council's Plant Breeding Institute in Cambridge. They incorporate the dwarfing gene from Norin 10, the Japanese dwarf strain on which Dr N. Borlaug's green revolution was based. In Britain, the new varieties go to the National Trials this year, and Dr F. G. H. Lupton, who heads the cereals division at Cambridge, estimates that they will produce at least 10 per cent more than their closest competitor. One snag is that the increase in yield is associated with a lower relative protein content, but in Britain and other developed countries, where the population is not dependent on cereals for protein, this is an economic rather than a nutritional problem.

Wheat with a high protein content is necessary for making the long-keeping bread which the British consumer now apparently prefers, which means that 60 per cent of the flour in a British loaf is imported from Canada or Australia. Dr Lupton is, however, hoping to increase the protein content of the semidwarf wheat so that the proportion of British flour used in bread-making can be increased.

So far, the new varieties seem to show good resistance to the yellow rust fungus. The institute now favours breeding for a degree of resistance to disease in general, rather than for complete specific resistance to known races of fungus. Its view is that varieties with specific resistance will sooner or later fall victim to new specific variants of yellow rust. Justification for this view has arisen this year with a serious attack of rust on the popular variety Joss Cambier, which until last year was resistant to all known races.

In specific resistance, plant cells attacked by fungus die and the pathogen is then unable to multiply. General resistance, like that of some of the older varieties of wheat, is genetically much more complicated and affords only limited protection. But unless circumstances are exceptionally favourable for the pathogen, as during this appalling summer, the infection will be too limited to affect yield seriously. In the meantime, the lesson of Joss Cambier is that farmers should grow several varieties of wheat.

\section{TELEVISION}

\section{Cuble TV Af Last}

from a Correspondent

BrITAIN has an extensive network of cable and wires capable of carrying a great many television programmes. This week, virtually for the first time,

\section{Second Nifure?}

Enquiry, Harrow County School for Boys' annual science journal, is as professional a job as ever. Larger than in the past, and leading off with articles by such luminaries as Sir Peter Medawar, one-time director of the National Institute for Medical Research, and Dr D. F. Shaw, fellow in physics at Keble College, Oxford, the journal presents its accustomed mixture of sixth form research, work by old boys now at university, accounts of visits to research establishments during the year, together with book and equipment reviews.

Among the original work contributed by the sixth forms are studies of the comparative toxicity of biological and conventional detergents and a continuing investigation into eye size mutants of Drosophila. Impeccably produced, Enquiry reaches a standard of presentation and content that any school could envy and its only tragedy is that this may be the last year the journal will appear as the Harrow County School's work. The school is to be converted into a high school, teaching only to $\mathrm{O}$ level, if the London Borough of Harrow's plans for comprehensive reorganization in the area go through (see Nature, 235, 298 ; 1972), as now seems likely. 